\title{
North American Jews in a Year-Long Volunteer Program in Israel: Identities, Motivations, Attitudes, and Hebrew Language Proficiency
}

\author{
Smadar Donitsa-Schmidt" ${ }^{*}$ Rivi Carmel \\ English Department, Kibbutzim College of Education, Tel-Aviv, Israel \\ Email address: \\ Smadar.donitsa $a$ smkb.ac.il (S. Donitsa-Schmidt), rivi.carmel $@$ ssmkb.ac.il (R. Carmel) \\ ${ }^{*}$ Corresponding author
}

\section{To cite this article:}

Smadar Donitsa-Schmidt, Rivi Carmel. North American Jews in a Year-Long Volunteer Program in Israel: Identities, Motivations, Attitudes, and Hebrew Language Proficiency. International Journal of Language and Linguistics. Vol. 6, No. 4, 2018, pp. 101-109. doi: $10.11648 /$ j.ij11.20180604.11

Received: June 1, 2018; Accepted: July 1, 2018; Published: July 24, 2018

\begin{abstract}
The study investigated a group of 68 young North American young adults who volunteered to teach English in Israeli public schools for a year in the framework of a joint project conducted by the Jewish Agency for Israel and the Israeli Ministry of Education entitled 'Israel Teaching Fellows' that was inaugurated in 2013. Employing a pre-post design, the research explored their motivations for joining the program as well as the changes in their self-ascribed identity, attitudes toward Israel and its culture, and gains in Hebrew language proficiency and knowledge about Israel. Findings showed that after spending a year in Israel, the participants gained more knowledge of Israel and improved their proficiency in Hebrew, but no changes were detected in their attitudes and Jewish identity.
\end{abstract}

Keywords: Identities, Motivations, Attitudes, Language Proficiency

\section{Introduction}

Israel is considered the homeland and a heritage country of Jews living in the Diaspora, with the largest group residing in the US. The desire to increase contacts and relationships between the State of Israel and the Diaspora Jews and to strengthen and intensify Jewish identity and commitment in the various Jewish communities around the world has led both the Israeli government and Jewish organizations to inaugurate various programs for the purpose of fulfilling their goals. One of the main components of these programs is a short- or long-term trip to Israel, the aim being to bring Jewish youth from all over to world to visit the country. By so doing, they will become acquainted with Israel, its culture, and its people, strengthen their Jewish identity, and create a stronger bond between the Jewish communities in the Diaspora and the State of Israel [1-3].

Previous studies have concluded that even very brief trips to Israel seem to realize these goals and exert a profound impact on the participants' Jewish identity and commitment to the Jewish people $[4,5]$. They also posited that participation in semester or year programs in Israel is directly linked to stronger Jewish affiliation regardless of the Jewish background while growing up in the diaspora [6]. However, most of the above-mentioned studies involved participants who came to Israel on a 10-day educational trip or on onesemester study abroad programs. In addition, most of these studies did no utilized a pre-post design.

The aim of the current research was to investigate one such group of young adults who spent a year in Israel as teaching fellows. The Israel Teaching Fellow (ITF) program was a new volunteer work-abroad program initiated jointly in 2013 by Israel's Ministry of Education and the Jewish Agency for Israel. The current study investigated its first cohort. Using a pre-post design, the research sought to focus on the impact of the program on the participants' Jewish identity, attitudes toward Israel and Judaism, and their level of Hebrew language proficiency. The research also investigated their motivations to join the program and the extent to which they became acquainted with Israel and Israeli society. 


\section{Jewish Identity}

Over the past centuries, there has been increasing interest in the concept of 'Jewish identity'. This interest was manifested in numerous research studies and projects dedicated to the understanding of its various aspects as well as in a plethora of educational and community programs aimed at strengthening Jewish identity [7]. It goes hand-inhand with the general growing attention accorded to the concepts of ethnic, racial, and religious identities and the ways in which both individuals and groups identify and define themselves in relation to others [8-10]. Among the central components of ethnic identity are self-identification, a sense of belonging, attitudes toward one's group, and ethnic involvement. The latter includes aspects such as language, religious practice, and active engagement in community activities [11].

It has been argued that while identity is central to the psychological well-being of members of ethnic and racial minority groups $[12,11]$, individuals might juggle between one identity and another and simultaneously hold more than one identity $[13,14]$. In a world of multifaceted identities that allows the individual greater freedom to choose his/her identity or identities than in the past, the search for identity becomes an inherent part of one's self. This search may include, for example, participation in local community activities, the study of a heritage language, or travel to countries of origin [15-19]. Since Jews in the diaspora have managed to maintain a balance between the perpetuation of a distinctive Jewish group identity and acculturation into the dominant host society, they are considered a classic case for the study of ethnicity and identity [20]. Jewish identity in this case has been found to be a multidimensional phenomenon consisting of ritualistic behavior, institutional participation, social ties, attitudes toward Israel, religious belief, knowledge of Judaism, and philanthropy [21, 22].

Zionism, and more specifically the creation of the State of Israel in 1948, has dramatically affected contemporary Jewish identity. Following centuries of diaspora and exile during which Israel was a utopian ideal, Jews were no longer required to live as an imagined community [23-25]. Yet, while some actively participated in the emerging Israeli national identity by immigrating to Israel, others established ties with Israel from their home countries. The strength and nature of the connection of Jews around the world with Israel is often regarded as an indicator of their Jewish identity [2628]. Their Jewish identity is therefore inextricably linked with their feelings, attitudes, and attachment vis-à-vis Israel and its history, land, people, and faith. Over the years, Israel has become included in diaspora identity through a range of issues including continuity and regular visits. The connection between Jewish adolescents and young adults with Israel has been a matter of particular interest for researchers [5, 29, 30]. Over the years, Israel, with the aid of numerous Jewish organizations worldwide, has also attempted to maintain close ties with Diaspora Jews. One avenue that was devised for achieving this goal was the establishment of programs that would allow Jewish young adults to visit Israel for a short period.

\section{Young Adults Visiting Israel}

The very first programs to be initiated in the 1960s were short study-abroad programs and visits to Israel sponsored by the World Zionist Organization [22]. Subsequently, in 1983, the 'one-year study-abroad program' was inaugurated with the intention of increasing the number of Jewish students coming to Israel for a year's study. The programs were all supported by the Jewish Agency, which subsidizes scholarships, overseas recruitment activities, the development of courses at the universities, accommodation for the students, and social activities during their stay. It was also resolved that the 'Israel Experience' was a key means of enriching Diaspora Jewish education [31-33].

In 1999, a new short-term program titled 'Birthright Israel' ('Taglit') was initiated for the purpose of bringing Jewish young adults aged 18-26 to Israel for a 10-day visit. During their trip, the participants - most of whom are visiting Israel for the first time - are encouraged to discover new meaning in their personal Jewish identity as well as a connection to Jewish history and culture. Research conducted on the Birthright programs has revealed that the participants accorded the trip a positive evaluation and reported on a meaningful Jewish experience. They expressed stronger Jewish identities, a greater commitment to marrying Jews only and raising children in the Jewish tradition, an increased understanding of Israeli society and history, and a stronger commitment to the State of Israel and to involvement in Jewish activities $[4,5]$.

In 2004, yet another new program called Masa ('journey' in Hebrew) was inaugurated [34]. This joint project of the Jewish Agency for Israel and the Israeli government serves as an umbrella organization for various short- and long-term programs for young Jewish adults. It includes a gap year, study abroad, internships, post-graduate programs, and volunteer work-abroad programs. The various programs within this project range from five to 12 months in duration and are intended for Jewish participants of between 18 and 30 years old. The participants all receive grants in order to subsidize the cost of the programs. According to the organization's website, over 100,000 individuals from more than 60 countries have participated in these programs since the founding of Masa in 2004.

In 2010, a study that surveyed over 13,000 Israel program participants, more than 11,000 of whom were Americans, and most of whom had been on a short-term Birthright experience or participated in a Masa program in the five preceding years, found participation in semester or year programs in Israel to be directly linked to stronger Jewish affiliation regardless of the program participants' Jewish background while growing up. The research also noted that the more time the participants spent in Israel, the greater their level of Jewish identification [6]. 


\section{The Research Context: Masa Israel Teaching Fellows}

In 2013, in a joint initiative of Israel's Ministry of Education and the Jewish Agency for Israel, a new volunteer work-abroad program titled the Masa Israel Teaching Fellows (ITF) was inaugurated [34]. This program was a year-long fellowship for college graduates between the ages of 21 and 30 who wished to teach English as a foreign language to Israeli Jewish children while immersing themselves in Israeli society. Applicants were Jewish college graduates from North America. They were placed in Jewish Hebrew-speaking public schools where they worked 25-30 hours per week. As part of their work, they tutored English in small-groups thereby reducing class sizes so that full-time teachers could work more effectively. They also assisted the English teachers in accordance with the students' and the school's specific needs. The schools, which were either elementary or junior-high schools, were all located in low socio-economic neighborhoods in peripheral areas of the country.

Upon arrival, the fellows underwent a six-week period of orientation in educational methods in one of the Israeli colleges of education and were afforded ongoing pedagogical support by the college. Although knowledge of Hebrew was not essential to serve as teaching fellows, the fellows received Hebrew instruction twice a week for the duration of the program. It was assumed that knowledge of the Hebrew language, one of Israel's official languages spoken by Jewish Israeli people, would help the teaching fellows to better communicate with the schoolchildren who are all native speakers of Hebrew. The teaching fellows resided in small groups in apartments within the local community where they worked. Throughout the year, they attended seminars on topics such as Israel and the Middle East, art and culture in Israel, and Israeli politics and society. They also went on several tours of the country in order to learn about Israel's history, society, culture, and geography.

In line with the abovementioned goal to maintain close ties with Diaspora Jews, Masa programs which include proactive recruitment of Jews to Israel by means of a variety of study and work programs serves the agenda of a transformative experience. The aims of these programs is to encourage immigration to Israel, to foster positive attitudes toward Israel, to strengthen Jewish identity, and to increase the commitment of Jews in the Diaspora [34].

Considering the above Masa acclaimed goals, the purpose of the current study was to examine whether participation in such a program is indeed a transformative experience. The study, which investigated one group of North American participants who volunteered to spend a year in the ITF program, focused on their motivations to join the program as well as on the changes in their self-ascribed identity, attitudes toward Israel and its culture, and gains in Hebrew language proficiency and knowledge of Israel. More specifically, the following research questions were addressed:

1. What were the participants' motivations to join the program?

2. What were the participants' attitudes toward the host culture, self-ascribed identities, and Hebrew language proficiency before and after the program?

3. To what extent did the participants increase their knowledge of various aspects related to Israel?

4. What were the correlations among participants' attitudes, identities, Hebrew proficiency, and knowledge of Israel in the pre- and post-contexts?

5. What did the participants consider to be the main gains of the year?

\section{Methodology}

\subsection{Participants}

The current study focused on a group of 68 American Jewish college undergraduates who participated in a one-year work-abroad volunteer program in Israel during the year 2013 (August 2012 until July 2013), serving as hands-on English tutors in Israeli public schools. The participants consisted of 24 males (35\%) and 44 females (65\%) ranging in age from 23 to $32(\mathrm{M}=26$; S. $\mathrm{D}=2.00$ - year of birth ranging from 1981 to 1990). They all held a Bachelor's degree in a variety of academic backgrounds. In terms of degree of Jewish religious observance, most of them (95\%) are secular, non-observant Jews. All participants (100\%) claimed English to be their first language with six participants $(9 \%)$ specifying Hebrew as an additional language spoken at home since it was the mother tongue of one of their parents. Furthermore, 57 percent of the respondents indicated that they had some prior knowledge of Hebrew as a result of participating in extracurricular Hebrew lessons or Hebrew language summer camps. Most of the participants (91\%) had visited Israel in the past and 60 percent reported having relatives in Israel. Regarding prior experience with teaching or working with children or youth either formally or informally, 49 percent claimed to have such experience.

\subsection{Research Instruments and Procedure}

The research instruments employed in this study were four self-report questionnaires that were administered at various stages throughout the year. In the scope of this article, we shall focus only on the first (pre) and fourth (post) questionnaires, which were almost identical. These two questionnaires were administered upon arrival in Israel in August (pre) and at the end of the year-abroad program in July (post). The questionnaires, which included both open and closed question types, were partially based on existing questionnaires [35] and partially created specifically to meet the needs of the current study and research population. The questionnaires comprised four main parts as described below.

Part one of the questionnaire consisted of 24 sociodemographic and background questions including parents' origin, level of education, and level of Hebrew knowledge; religious affiliation; level of education; previous exposure to 
Hebrew and Hebrew language-learning; prior experience in teaching and working with children and youth; previous contacts with and visits to Israel; presence of relatives and family members in Israel; and intentions of remaining in Israel upon completion of the program. This part also included 15 Likert scale items structured as statements ranging from (1) 'disagree completely' to (5) 'agree completely' that examined participants' motivations to apply to and join the ITF program in Israel. These motivational items appeared only in the first questionnaire. Based on an exploratory factor analysis with a non-orthogonal rotation, the following six motivational factors emerged: (1) Getting to know Israel and its culture (4 items; $\alpha=.82$ ); (2) Contributing to Israeli society by improving the level of English in Israel (2 items; $\alpha=.82$ ); (3) Learning Hebrew (2 items; $\alpha=.81$ ); (4) Strengthening my Jewish identity (3 items; $\alpha=.80$ ); (5) Acquiring teaching skills (2 items; $\alpha=.73$ ); (6) Experiencing living in a different country ( 2 items; $\alpha=.60$ ).

Part two of the questionnaire contained 28 attitudinal items regarding Israel and its language, culture, religion, and people. All items were structured as statements on a 5-point Likert scale ranging from 'disagree completely' (1) to 'agree completely' (5). This part was construct-validated by subjecting it to an exploratory factor analysis with an orthogonal rotation. The analysis yielded the following attitudinal factors: (1) Importance of Hebrew language for Jews (3 items; $\alpha=.64, \alpha=.80$ ); (2) Attitudes toward the importance of Israel for Jews (5 items; $\alpha=.87, \alpha=.91$ ); (3) Attitudes toward Israeli culture and people (5 items; $\alpha=.74$, $\alpha=.85$ ); (4) Desire to live in Israel (2 items; $\alpha=.79, \alpha=.91$ ); (5) Attitudes toward my Jewish identity (4 items; $\alpha=.80$, $\alpha=.87$ ); (6) Attitudes toward the importance of preserving the Jewishness of the Jewish people ( 3 items; $\alpha=.57, \alpha=.73$ ); (7) Attitudes toward the degree to which the American Jewish community should be involved in and responsible for Jewish and Israeli existence ( 6 items; $\alpha=.83, \alpha=.87$ ). A general attitudinal factor was also created $(\alpha=84, \alpha=87)$.

This part also contained nine items related to the participants' knowledge concerning the Israeli state (e.g., history, culture, demography, current affairs) (9 items; $\alpha=.93$, $\alpha=.69$ ) as well as items related to the teaching of English. The latter will not be discussed in the scope of the current article.

Part 3 of the questionnaire dealt with the participants' selfascribed identity. Respondents were asked to rate the degree to which they identified themselves as being North
American, Jewish, and Israeli, each identity ranging from 'very weak' (1) to 'very strong' (5) on a 5-point Likert Scale.

In part 4 of the questionnaire, participants were asked to self-assess their Hebrew language proficiency using 16 cando items ranging from 'not at all' (1) to 'very well' (5). Four factors were extracted from this section: (1) Hebrew reading skills (4 items; $\alpha=.86, \alpha=.79$ ); (2) Hebrew speaking skills (4 items; $\alpha=.93, \alpha=.89$ ); (3) Hebrew writing skills (4 items; $\alpha=.80, \alpha=.81$ ); and (4) Hebrew listening comprehension skills (4 items; $\alpha=.92, \alpha=.86$ ). It is important to note that each language skill included both basic interpersonal communicative skills such as reading road signs, ordering food at a restaurant, writing a simple note to a friend, and understanding an Israeli giving simple directions, as well as more academically demanding activities such as reading a novel, giving a formal presentation, writing an academic paper, and understanding a lecture in Hebrew. A general proficiency score was computed as well $(\alpha=.95, \alpha=.96)$. Finally, using an open-ended question in the post questionnaire, the participants were asked about the main gains they felt they had derived from the year-long experience.

\section{Findings}

\subsection{Reasons for Joining the Program}

The participants indicated five main reasons, which were of equal importance, to explain their participation in the ITF program. The five reasons were as follows: (1) to learn Hebrew $(M=4.51 ; S D=0.66)$; (2) to have an experience $(M=4.47 ; S D=0.68)$; (3) to contribute to Israeli society $(M=4.34 ; S D=0.64)$; (4) to become acquainted with Israel and Israeli culture $(M=4.23 ; S D=0.67)$; and (5) to acquire teaching skills $(M=4.10 ; S D=0.89)$. Strengthening Jewish identity was ranked significantly lower $(M=3.18 ; S D=1.12)$.

\subsection{Attitudes Toward the Host Culture, Jewish Identity, and Hebrew Language Proficiency}

The changes that occurred between the pre- and the post contexts were analyzed by means of a series of dependent sample t-tests for attitudes toward the host culture, Jewish identity, and Hebrew language proficiency. Means, standard deviations and t-test values are presented in Table 1. Higher means indicate more positive attitudes, stronger identification, and greater Hebrew language proficiency.

Table 1. Differences between pre and post contexts in attitudes, self-ascribed identity, and self-assessed Hebrew language proficiency.

\begin{tabular}{|c|c|c|c|c|c|}
\hline & \multicolumn{2}{|l|}{ PRE } & \multicolumn{2}{|c|}{ POST } & \multirow{2}{*}{$t(\mathbf{p})$} \\
\hline & $M$ & $S D$ & $M$ & SD & \\
\hline \multicolumn{6}{|l|}{ Attitudes toward: } \\
\hline Importance of Hebrew language & 3.60 & 0.77 & 3.53 & 0.96 & -0.38 \\
\hline Importance of Israel to Jews & 3.87 & 0.89 & 3.83 & 0.87 & -0.30 \\
\hline Israeli culture and people & 4.02 & 0.61 & 3.99 & 0.73 & -0.24 \\
\hline Desire to emigrate and live in Israel & 3.08 & 1.00 & 3.25 & 1.43 & 0.75 \\
\hline Jewish identity & 3.57 & 0.96 & 3.53 & 1.02 & -0.28 \\
\hline $\begin{array}{l}\text { Commitment of North American Jews to Israel } \\
\text { Self-identification as: }\end{array}$ & 3.72 & 0.68 & 3.63 & 0.58 & -0.68 \\
\hline
\end{tabular}




\begin{tabular}{|c|c|c|c|c|c|}
\hline & \multicolumn{2}{|l|}{ PRE } & \multicolumn{2}{|c|}{ POST } & \multirow{2}{*}{$t(\mathbf{p})$} \\
\hline & $M$ & $S D$ & $M$ & $S D$ & \\
\hline North American & 4.35 & 1.07 & 4.08 & 0.99 & $-2.05^{*}$ \\
\hline Jewish & 4.23 & 1.09 & 4.23 & 1.02 & .00 \\
\hline Israeli & 1.87 & 1.28 & 2.23 & 0.58 & $2.14 *$ \\
\hline \multicolumn{6}{|l|}{ Hebrew self-assessment in: } \\
\hline Reading & 1.98 & 0.88 & 2.81 & 0.82 & $6.60 * * *$ \\
\hline Speaking & 2.11 & 1.25 & 3.28 & 0.98 & $7.00 * * *$ \\
\hline Listening & 1.68 & 0.86 & 2.66 & 0.84 & $8.11 * * *$ \\
\hline Total Hebrew proficiency & 1.95 & 0.90 & 2.94 & 0.80 & $7.92 * * *$ \\
\hline
\end{tabular}

${ }^{*} p<.05 * * p<.01 * * * p<.001$

As noted in Table 1, after spending a year in Israel, no significant changes were found in any of the seven attitudinal factors. Participants who elected to volunteer in the ITF program exhibited positive attitudes toward Israel and Israeli culture and people at both points in time $(M=4.02, M=3.99)$. They also considered the State of Israel to be important to the Jewish people $(M=3.87 ; M=3.83)$ and agreed to a large extent that the Jewish community in North America should be committed to supporting Israel $(M=3.72, M=3.63)$. The Hebrew language was also considered to be an important language at both points in time $(M=3.60, M=3.53)$, as were the attitudes toward their own Jewish identity $(M=3.57$, $M=3.53)$. Attitudes toward the need to preserve the Jewish religion, which were initially very mediocre, seem to have strengthened slightly, albeit not in a statistically significant manner $(M=2.61, M=2.81 ; t=1.82 ; p=.07)$. While there seemed to be no major desire among the participants to immigrate to Israel on a permanent basis, they also did not rule out this option $(M=3.08, M=3.25)$. In conclusion, the data indicate that year-long sojourn in Israel did not have any significant impact on the participants' attitudes toward Israel and its culture, people, language, and religion, which were generally favorable to begin with.

Regarding participants' identity, a comparison between the pre- and the post contexts indicates a slight but significant decrease in the North American identity, which was high at both times $(M=4.35, M=4.08)$, a slight but significant increase in the Israeli identity, which remained the lowest at both times $(M=1.87, M=2.23)$, and no change at all in the
Jewish identity, which was also high at both times $(M=4.23)$. Nonetheless, despite the significant differences between the beginning and the end of the year, there are no significant differences in the ordering of the identities in the pre- and post contexts between the Jewish identity and the North American identity, which were both high (PRE: $t=0.89$; $p>.05$; POST: $t=0.70, p>.05)$. On both occasions, the Israeli identity was significantly lower.

As can also be seen in Table 1, after a year in Israel, there was a significant increase in students' perceived level of Hebrew proficiency in all four skills. Despite the students' Jewish background and their previous exposure to Hebrew, the reported level of proficiency at the beginning of the year was very low and ranged from a mean of 1.68 in listening comprehension to a mean of 2.11 in speaking. At the end of the year, the participants assessed themselves as more competent, with means ranging from 2.66 in listening comprehension to 3.28 in speaking. The greatest improvement occurred in listening comprehension $(t=8.11)$ and in speaking $(t=7.00)$.

\subsection{Knowledge of Various Aspects Related to Israel}

Changes between the pre- and post-contexts pertaining to the participants' knowledge of various aspects related to the state of Israel were analyzed via a series of dependent sample t-tests. Means, standard deviations, and t-test values are presented in Table 2 with higher means indicating more knowledge.

Table 2. Differences between pre-and post-contexts in knowledge regarding Israel.

\begin{tabular}{|c|c|c|c|c|c|}
\hline \multirow{2}{*}{ Knowledge of: } & \multicolumn{2}{|l|}{ PRE } & \multicolumn{2}{|c|}{ POST } & \multirow{2}{*}{$t(\mathbf{p})$} \\
\hline & $M$ & $S D$ & $M$ & SD & \\
\hline Demographic composition & 2.70 & 1.04 & 3.95 & 0.74 & $8.06 * * *$ \\
\hline History of Zionism & 2.78 & 1.02 & 3.60 & 0.93 & $4.82 * * *$ \\
\hline Internal affairs & 2.80 & 0.91 & 3.68 & 0.79 & $6.27 * * *$ \\
\hline Relations between Israel and the Diaspora & 2.85 & 1.23 & 4.00 & 0.88 & $5.39 * * *$ \\
\hline Ancient Jewish history & 2.85 & 1.00 & 3.18 & 1.01 & 1.77 \\
\hline Geography of the state & 3.00 & 1.09 & 4.13 & 0.64 & $6.53 * * *$ \\
\hline Relations with Arab countries & 3.20 & 1.09 & 3.83 & 0.78 & $3.38 * *$ \\
\hline Recent history of Israel & 3.23 & 0.94 & 3.88 & 0.79 & $4.76 * * *$ \\
\hline Total knowledge of Israel & 2.95 & 0.77 & 3.82 & 0.58 & $7.92 * * *$ \\
\hline
\end{tabular}

$* * p<.01 * * * p<.001$.

As noted in Table 2, although the participants came with some knowledge of the various aspects of the Israeli state, after spending a year in Israel, they were significantly better informed $(t=7.92 ; p<.001)$. Areas in which they gained more 
knowledge include the demographic composition of the country $(t=8.06)$, the geography of the state $(t=6.53)$, and the country's internal affairs $(t=6.27)$. The only aspect in which no significant difference was found was knowledge of ancient Jewish history. It is worthwhile noting that the participants were initially more knowledgeable about the recent history of Israel and the political situation, including the relations with Arab countries $(M=3.23, M=3.20$ in the pre- context, respectively).

\subsection{Correlations Among Attitudes, Identities, Hebrew Proficiency, and Knowledge of Israel}

Correlations among the participants' attitudes, identities, Hebrew proficiency, and knowledge of Israel were examined by means of Pearson correlations. The correlations are presented in Table 3.

Table 3. Correlations among attitudes, identities, Hebrew proficiency, and knowledge of Israel in the pre-context (upper) and post context (lower).

\begin{tabular}{|c|c|c|c|c|c|c|}
\hline & Attitudes & NA ID & Jewish ID & Israeli ID & Hebrew Prof. & Knowledge \\
\hline Attitudes & - & & & & & \\
\hline North American identity & .04 & - & & & & \\
\hline Jewish identity & $.51 * * *$ & .06 & - & & & \\
\hline Israeli identity & $.29 * *$ & .04 & .15 & - & & \\
\hline Hebrew Proficiency & $.33 * *$ & .00 & $.26^{*}$ & $.28^{*}$ & - & \\
\hline Knowledge of Israel & $.45 * * *$ & .03 & $.34 * *$ & .11 & $.45 * * *$ & - \\
\hline Attitudes & - & & & & & \\
\hline Jewish identity & $.57 * * *$ & .11 & - & & & \\
\hline Israeli identity & $.40 * *$ & -.07 & .20 & - & & \\
\hline Hebrew Proficiency & $.32 *$ & .18 & $.24 *$ & $.52 * * *$ & - & \\
\hline Knowledge of Israel & $.36 * *$ & .15 & $.27 *$ & $.26^{*}$ & $.37 * *$ & - \\
\hline
\end{tabular}

$* p<.05 * * p<.01 * * * p<.001$.

Generally, a similar picture emerges in the above table regarding the correlations among the research variables in the pre- and post-contexts. Participants who portrayed positive attitudes toward Israel and Israeli culture also tended to strongly identify themselves not only as Jewish $(r=.51, r=.57$ : $p<.001)$ but also as Israelis $(r=.29, r=.40 ; p<.01)$, with correlations growing stronger at the end of the year. Positive attitudes are also positively and significantly correlated with the level of Hebrew proficiency $(r=.33, r=32)$ and knowledge of Israeli society $(r=.45, r=.36)$. Jewish identity and even more so Israeli identity are positively and significantly correlated with Hebrew language proficiency, especially at the end of the year (post: $r=.24, r=.52$ ), and with a higher degree of acquaintance with Israeli society (post: $r=.27, r=.26$ ). Finally, Hebrew language proficiency is found to be significantly correlated with the knowledge of Israeli society $(r=.45, r=.37)$. North American identity does not seem to correlate with any of the other variables.

\subsection{Most Memorable Experiences During the Year}

The participants' responses to the open-ended question posed at the end of the year, asking them about their perceived main gains during that period, were thematically categorized. Since respondents had given answers that fit more than one category the percentages presented herewith add to more than one hundred. Five main categories emerged from their responses: (1) individual growth and development $(65 \%)$ which included maturity, responsibility, becoming more open and adventurous, learning new things, and coping with challenges; (2) becoming acquainted with Israeli culture (48\%); (3) the teaching experience gained in school (48\%); (4) the general experience (45\%), which included having fun, meeting new people, and experiencing a different routine; and (5) strengthening Jewish identity (35\%).

\section{Discussion}

The new Israeli Teaching Fellow program inaugurated in 2013 is one of the many study and work programs operated by the Jewish Agency and the Israeli government with the intention of fostering Jewish identity among Diaspora Jews. Its goals aim at maintaining close contact with Jewish communities outside Israel in the hopes that some of the fellows decide to make Israel their permanent home while the others remain supportive of Israel upon their return to their own Jewish communities. From this point of view, such program and other similar ones hold traditional views of the notion of the diaspora which entails a diasporic return [36], namely, the return of Jews to their homeland, Israel. In that sense, the Masa program has a very clear agenda of encouraging immigration to Israel, fostering positive attitudes toward Israel, strengthening Jewish identity, and increasing the commitment of Jews in the Diaspora. It is therefore only reasonable to ask ourselves about the extent to which these programs achieve their goals. The research focused on the first cohort of the ITF program that comprised 68 young North American adults who came to Israel for a year as volunteers to teach English to children in Israeli public schools.

Findings of the current research reveal that after spending a year in Israel, no change at all was detected in the participants' attitudes toward Israel and its culture. They did not manifest a stronger desire to immigrate to Israel, nor did they express more favorable attitudes either toward their Jewish identity or toward the importance of preserving this identity by ensuring that Jews only marry Jews. 
Consistent with the lack of change in participants' attitudes, no change was found in their self-identification as Jewish. These findings run counter to those of previous research that found more favorable attitudes as a result of a visit to Israel-even after a much shorter one such as a Birthright visit [37] or after a five-month study-abroad program [35]. Since it was maintained that the longer the program participants spent in Israel, the greater their level of Jewish identification would be, the expectation in our case would be for at least some change [6]. Indeed, one can argue that most of participants' attitudes were positive to begin with, which explains the lack of change in them. This is not entirely so, however. While the level of the attitudes toward Israel and its culture and people was high, the level of the rest of the attitudinal factors was lower; therefore, this does not seem to be a convincing argument for the lack of change. The level of attitudes toward the preservation of Jewishness among the Jewish people was, in fact, very low, indicating a lack of agreement with items such as 'Jews should not intermarry'. We would like to furnish three possible explanations for the above results.

The first explanation is associated with the nature of the sojourn in Israel. While the short-term visits are only touristic in nature and clearly reflect the agenda of its organizers, namely, of transmitting the simplified version of the so-called Jewish-Zionistic narrative to its participants [38], a long-term stay in Israel is no longer able to frame Israel's story in a linear, naïve, and one-dimensional manner. Being immersed in Israeli society for a whole year, living in local communities (and not in dormitories, as is usually the case with study-abroad programs), and working in low socioeconomic neighborhoods cannot impose strict, sterile, and unrealistic control on the sights, experiences, and stories to which the participants are exposed. Crafting the visit in a manner that would create a powerful spiritual and emotional experience by employing high-level control of time and space, as is achieved in short visits [38] is no longer a possibility in a year-abroad experience such as this. While the participants in a short visit are exposed to visiting key religious and national sites and hearing heroic stories of past and present times as well as testimonials from inspiring people, the teaching fellows experienced some of the less pleasant everyday life situations in Israel and were exposed to hardships within the Israeli society at large and the school system in particular. In a short trip, it is perhaps possible to teach Israel through a single narrative; conversely, during a longer sojourn, one cannot avoid seeing that the Israel of today is composed of a multiplicity of visions and voices, and that Israelis themselves do not share the same narrative. In an experience that is less formulaic in character, it is therefore impossible to guarantee its effect on the participants and its success in the creation of more positive attitudes and a higher level of identification with Judaism and the Jewish people. Perhaps the 'good news' resides in the fact that the participants' initial favorable dispositions did not deteriorate with time, as was found in some research [22, 39].

A second explanation of the lack of change in the participants' attitudes and Jewish identity may be linked to the 'distancing' of American Jewry from Israel [1, 40, 41]. This narrative of American Jewish disengagement from Israel, particularly among young adults, has grown stronger in the past years since the 1988 Palestinian Intifada and the political debate concerning the conflict between Israel and the Palestinians [42, 43]. Although this discussion of the relationship between American Jews and Israel has become a prominent topic of discourse in the Jewish world, it has been argued that neither the scholarly literature nor survey evidence consistently supports the view that attachment to Israel is declining among American Jews [44, 45]. The findings of the current research do seem to indicate that this is a possibility. They also show that at the end of the year, there was a less powerful correlation between the level of Jewish identity and knowledge of Israel, which is perhaps indicative of the fact that greater knowledge of the country leads to a decrease in the level of Jewish identification.

A third proposed explanation of the lack of improvement in the participants' attitudes and an increase in their Jewish identity relates to their motivations to come to Israel. They were more interested in instrumental benefits such as improving their language skills, having 'an experience', acquiring teaching skills, and becoming acquainted with Israel. Strengthening their Jewish identity was rated the lowest on their list of motivations to come to Israel and was also the last gain to be mentioned after the year was over.

The existence of a mixture of motivations that was found in this research is consistent with previous research showing that Jewish youngsters who decide to visit Israel have complex expectations, aspirations, and motivations regarding their decision. They are not interested in any single aspect of Israel but in a total 'Israel experience' [2]. Nonetheless, the question remains as to why Jewish identity was the last on their list. In the scope of the present research, we are unable to answer this question: we can only suggest that this may be connected to their age, since they are older than the average youngsters who visit Israel in the context of the Birthright project and are therefore less interested in an identity search.

So what did the participants gain during this year? Despite their Jewish background, which included exposure to Hebrew, their level of Hebrew proficiency to begin with was very low. Yet, at the end of a year's study, they reported a huge improvement in all language skills. While these substantial linguistic gains were probably partially a result of the participants' formal Hebrew language lessons, they were also attributable to the fact that the students mingled in Israeli society - particularly as a result of the work in school, which necessitated that they communicate with children with English skills that were still very basic and sometimes nonexistent. The improvement in Hebrew proficiency is especially noteworthy considering the dominant role that English plays in Israeli society. For English-speaking people, using Hebrew is not an easy task when there are so many determined English-speaking Israelis who refuse to use Hebrew when afforded an opportunity to practice their English. Thus, English-speakers usually have the option of 
reverting to their native tongue, thereby rendering the challenge of acquiring Hebrew in Israel even more daunting.

Bearing in mind that learning Hebrew constituted the participants' primary motivation to come to Israel, this goal was certainly achieved. Although these findings cannot be compared to research conducted on the short visits to Israel, similar findings were obtained on Jewish students' studyabroad in Israel [35, 36]. Findings also show that the participants became increasingly informed about Israel and its politics, history, geography, and current affairs. This broadening of knowledge regarding Israel and Israeli culture was also one of their main motivations to spend time in Israel. It is reasonable to assume that some of this information was obtained in an informal manner during the year and some was garnered during the tours and lectures provided throughout the year.

Apart from investigating changes as a result of the yearabroad experience, this study also attempted to explore the possible relationships among attitudes, Jewish identity, knowledge of the host country and culture, and secondlanguage proficiency. Findings of the current study support the literature, suggesting a link between social identity, language proficiency, and attitudes [47]. The students whose attitudes toward Israel and its language, culture, and people were more positive were the ones who displayed a considerable improvement in their Hebrew proficiency and were also more inclined to acquire more knowledge of Israeli society. Identity was also found to be correlated with language gains. The students who identified themselves more as Israelis were the ones who made the greatest progress in their Hebrew proficiency, thus reflecting the powerful connection between acculturation and language proficiency [48].

In conclusion, concerned with the issues of assimilation and intermarriage, the Jewish community has developed a number of initiatives designed to reinforce engagement with Jewish life among young Jewish adults and to foster their ties with Israel-travel to Israel being one such initiative. The underlying assumption of travel to Israel has posited that 'the more the better', or in other words, "the more frequently people travel to Israel for longer stays, the better off they are as educated and engaged Jews" [38, p. 218]. Yet, as noted by the same author, "the Israel education field has not produced a comprehensive theory of travel that takes into account philosophical, cultural, developmental, and methodological factors. The design and the implementation of programs are not based on universal and well-grounded theoretical foundations" (p. 218). This is perhaps why the findings of the current research do not reveal the 'transformative change' that the program initiators anticipated.

\section{Conclusion}

On a personal note, as academics and educators living and working in Israel, we believe in the importance of continued arrival of delegations of young Jewish adults from the diaspora. While 'transformative change' may not have taken place with this particular cohort, nonetheless, the experiences they have accumulated while visiting Israel during this intensive year-long program were significant and meaningful. As such, they have contributed to their knowledge and understanding of Israel, its people and culture. We believe this, in itself, is an important element for fostering the future connection between Jewish young adults and the State of Israel.

Clearly, further research on the ITF program is required since the current research investigated only its very first cohort, which was a small one. Additional research on these groups and on the long-term stays in Israel is also necessary. Moreover, since the added benefit for Israel is assistance in teaching English in schools, it is also in the country's interest to further investigate these aspects.

\section{References}

[1] Ben-Moshe, D. \& Segev, Z. (2007). Israel, the Diaspora and Jewish Identity. Brighton: Sussex Academic Press.

[2] Cohen, H. E. (2003). Tourism and religion: A case study of visiting students in Israeli universities. Journal of Travel Research, 42(1), 36-47.

[3] United Jewish Communities. (2003). National Jewish Population Survey 2000-2001: Strength, challenge and diversity in the American Jewish population. New York: UJC Publications.

[4] Saxe, L., Phillips, B., Sasson, T., Hecht, S., Shain, M., Wright, G., \& Kadushin, C. (2011). Intermarriage: The impact and lessons of Taglit-Birthright Israel. Contemporary Jewry, 31(2), 151-172.

[5] Saxe, L., \& Chazan, B. (2008). Ten days of Birthright Israel: A journey in young adult identity. Waltham, MA: Brandeis University Press.

[6] Cohen, S. M., \& Kopelowitz, E. (2010). Journeys to Israel: The impact of longer-term programs upon Jewish engagement and Israel Attachment. New York: Jewish Agency for Israel.

[7] Cohen, E. H. (2010). Jewish identity research: A state of the art. International Journal of Jewish Education Research, 1(1), 7-48.

[8] Barth, F. (2012). Boundaries and connections. In A. P. Cohen (Ed.), Signifying identities (pp. 25-44). New York: Routledge.

[9] Goffman, E. (2017). Interaction ritual: Essays in face-to-face behavior. London: Routledge.

[10] Tajfel, H. (Ed.). (2010). Social identity and intergroup relations. Cambridge: Cambridge University Press.

[11] Phinney, J. S., Jacoby, B., \& Silva, C. (2007). Positive intergroup attitudes: The role of ethnic identity. International Journal of Behavioral Development, 31(5), 478-490.

[12] Berry, J. W., Phinney, J. S., Sam, D. L., \& Vedder, P. (2006). Immigrant youth: Acculturation, identity, and adaptation. Applied psychology, 55(3), 303-332.

[13] Berry, J. W. (2003). Conceptual approaches to acculturation. In K. Chun, P. Balls-Organista, \& G. Martin (Eds.), Acculturation: Advances in theory, measurement, and applied research (pp. 17-37). Washington DC: American Psychological Association Press. 
[14] Sam, D. L., \& Berry, J. W. (Eds.). (2006). The Cambridge handbook of acculturation psychology. Cambridge: Cambridge University Press.

[15] Avni, S. (2011). Toward an understanding of Hebrew language education: Ideologies, emotions, and identity. International Journal of the Sociology of Language, 208, 53-70.

[16] Ari, L. L. (2012). North Americans, Israelis, or Jews? The ethnic identity of immigrants' offspring. Contemporary Jewry, 32(3), 285-308.

[17] Kelner, S. (2012). Tours that bind: Diaspora, pilgrimage, and Israeli birthright tourism. NY: NYU Press.

[18] Kelner, S. J. (2002). Almost pilgrims: Authenticity, identity and the extraordinary on a Jewish tour of Israel. (Doctoral dissertation, City University of New York).

[19] Safran, W. (2005). The Jewish diaspora in a comparative and theoretical perspective. Israel studies, 10(1), 36-60.

[20] Hart, M. B. (2000). Social science and the politics of modern Jewish identity. Stanford: Stanford University Press.

[21] Herman, S. (1988). Jewish identity: A social psychological perspective. Beverly Hills: Sage Publishers.

[22] Herman, S. (1970). American students in Israel. New York: Cornell University Press.

[23] Friedman, M. L., Friedlander, M. L., \& Blustein, D. L. (2005). Toward an Understanding of Jewish Identity: A Phenomenological Study. Journal of Counseling Psychology, 52(1), 77 .

[24] Dash-Moore, D., \& Troen, S. (Eds). (2001). Divergent Jewish cultures: Israel and America. New Haven, CT: Yale University Press.

[25] Altman, A. N., Inman, A. G., Fine, S. G., Ritter, H. A., \& Howard, E. E. (2010). Exploration of Jewish ethnic identity. Journal of Counseling \& Development, 88(2), 163-173.

[26] Auerbach, J. (2001). Are we one? Jewish identity in the United States and Israel. New Brunswick, NJ: Rutgers University Press.

[27] Ezrahi, E. (2001). In search of roots and routes: Remaking of the diasporic Jewish identity. Jerusalem: Moriya, Department for Jewish Zionist Education, Jewish Agency for Israel.

[28] Ari, L. L., Mansfeld, Y., \& Mittelberg, D. (2003). Globalization and the role of educational travel to Israel in the ethnification of American Jews. Tourism Recreation Research, 28(3), 15-24.

[29] Cohen, E. H. (2008). Youth tourism to Israel: Educational experiences of the diaspora. Clevedon, UK: Channel View Publications.

[30] Zisenwine, D. W. (Ed.). (2003). Knowing what: Jewish Culture, Identity, and Language. School of Education, Tel Aviv University.

[31] Saxe, L., \& Chazan, B. I. (2008). Ten days of Birthright Israel: A journey in young adult identity. Hanover and London: University Press of New England.
[32] Lev Ari, L., \& Mittelberg, D. (2008). Between authenticity and ethnicity: Heritage tourism and re-ethnification among diaspora Jewish youth. Journal of Heritage Tourism, 3(2), 79103.

[33] Feuer, A. (2009). Jewish intragroup convergence and divergence in the university Hebrew class. University of Maryland Press.

[34] Masa Israel Journey (2015). http://www.masaisrael.org/

[35] Donitsa-Schmidt, S., \& Vadish, M. (2005). North American Students in Israel: An Evaluation of a Study Abroad Experience. Frontiers: The Interdisciplinary Journal of Study Abroad, 11, 33-56.

[36] Canagarajah, S., \& Silberstein, S. (2012). Diaspora identities and language. Journal of Language, Identity \& Education, $11(2), 81-84$.

[37] Saxe, L., Fishman, S., Shain, M., Wright, G., \& Hecht, S. (2013). Young Adults and Jewish Engagement: The Impact of Taglit-Birthright Israel. Massachusetts: Brandeis University, Maurice and Marilyn Cohen Center for Modern Jewish Studies.

[38] Ezrachi, E. (2015). Educational travel to Israel in the era of globalization, Journal of Jewish Education, 81 (2), 212-225.

[39] Sasson, T., Mittelberg, D., Hecht, S., \& Saxe, L. (2011). Guest-host encounters in Diaspora-heritage tourism: The Taglit-Birthright Israel mifgash (encounter). Diaspora, indigenous, and minority education, 5(3), 178-197.

[40] Heilman, S. (2010). Editor's introduction to the distancing hypothesis issue. Contemporary Jewry, 30(2-3), 141-143.

[41] Waxman, C. I. (2010). Beyond Distancing: Jewish Identity, Identification, and America's Young Jews. Contemporary Jewry, 30(2-3), 227-232.

[42] Shain, Y. (2007). Kinship and Diasporas in International Affairs. Ann Arbor, MI: University of Michigan Press.

[43] Sheffer, G. (2003). Diaspora Politics: At Home Abroad. New York: Cambridge University Press.

[44] Cohen, S. M., \& Kelman, A. (2007). Beyond distancing: Young adult American Jews and their alienation from Israel. New York: Andrea and Charles Bronfman Philanthropies.

[45] Sasson, T., Kadushin, C., \& Saxe, L. (2010). Trends in American Jewish attachment to Israel: An assessment of the "distancing" hypothesis. Contemporary Jewry, 30(2-3), 297319.

[46] Parry, J. (2014). Experiences with study abroad in Israel: Heritage status and Hebrew. HHE, 16, 37-64. http://ivrit2015.macam.ac.il/heb/Documents/HHE_16_2014_4 0-67.pdf

[47] Giles, H. (Ed.). (2012). The handbook of intergroup communication. NY \& London: Routledge.

[48] Berry, J. W., Phinney, J. S., Sam, D. L., \& Vedder, P. E. (2006). Immigrant youth in cultural transition: Acculturation, identity, and adaptation across national contexts. Lawrence Erlbaum Associates Publishers. 